\title{
Research on the Education System of Industry College -- Set the Environmental Design Major of Shandong Yingcai University as an Example
}

\author{
Yuzhi Zhu \\ Shandong Yingcai University, Ji'nan Shandong, 250104, China
}

\begin{abstract}
Keywords: Industry College, Education System, Environmental Design.
\end{abstract}
\begin{abstract}
This paper starts from the current situation of industry college, introduces some domestic and overseas research achievements and practices, combining the reality of Shandong Yingcai University to introduce its achievements on the aspects of cooperative education between university and enterprises, building a community of university-enterprise cooperation, construction of university-enterprise cooperation information management platform; to state the experience of the environmental design major on talent cultivation, students' improvement on application ability, teachers' quality enhancement and construction of training base.
\end{abstract}

\section{Overview of industry college}

The overseas research on the education system of industry colleges should be started from the university-enterprise cooperation mode. At the earliest, Joseph Schumpeter put forward the concept of innovation in The Theory of Economic Development in 1912, later scholars like Rosberg, etc. put forward the three features (dynamic, collection and integration) of innovation process in the early 1980s. These views brought universities and research institutes into the main body of innovation, made them become innovation subject together with enterprises, which further laid the theoretical foundation for university-enterprise cooperative innovation. In 1987, British Professor Freeman put forward in Technical and Economic Operation: Experience from Japan that university-enterprise cooperation is a national action and formed the "Triple helix (body)" of University-Industry-government in the concept of "National Innovation System", cleared out the government's important role in university- enterprise cooperation. Henry Etzkowitz and Loet Leydesdorff thought that "the tentacle of university and enterprise begin to stretch to the other's field”. All these laid a theoretical foundation for the further research on the cooperative mechanism between enterprises and universities.

German "Dual System”, American “Cooperative Education”, British "Studying for Alternate”, Japanese "Industry-academy Cooperation", Australian "TAFE” mode, Russian "College - Base Enterprise System" mode and Singaporean "Teaching Factory", all these formed effective and diversified university-enterprise cooperation mode with different features that are suited for their own country. Among which, the "Dual System" is an education system that supported by legalization and constructed by the cooperation between universities and enterprises, that is to say enterprises and universities share the tasks of talent training, organize teaching and on-the-job training according to enterprises' requirements on talents.

In 1985, The Decisions of the Central Committee of the CCP on Education Reform formally put forward that universities carry out university-enterprise cooperation in school running together with enterprise and public institution, the national 11th five-year development plan in 2006 put forward the grant blueprint that "strive to develop the talents training mode that taking employment as the orientation, vigorously promote university-enterprise cooperation, work-integrated learning”. Under the guidance of the national macro-economic policy, university-enterprise cooperation gradually becomes a new education mode in the reform practice of colleges and universities. 
In recent years, explorations on the university-enterprise education system gradually become research hotspots. $\mathrm{Zu}$ Tingxun, etc. analyzed the dynamic factor and cooperation mode of university-enterprise cooperation from the aspect of new institutional economic; Ding Houde, etc. researched the national innovation system theories, integrated national objectives and national strategy into university-enterprise cooperation, established the important role of university-enterprise cooperation in our country. Wu Xiaoyan (2007) analyzed the influence factors and cooperative mechanism of university-enterprise cooperation from the knowledge demand and cooperation value of university and enterprises; Li Jiang studied the theoretical and actual problems of the long-term effect of university-enterprise-research cooperation from the aspect of new institutional economics; Jiang Dan analyzed the innovative university-enterprise cooperation mode from the macro and micro angle; Wang Chongwei (2009) summarized three kinds of university-enterprise cooperation modes: university-owned enterprise, industry-oriented education and cooperative education; Zhang Lian's theories on cooperative education and the definition of practice are representative in our country. ${ }^{[1]}$ Besides researches on theories, some universities have practiced on the industry college. November 26, 2013, our country opened university education system-seminar on industry college pilot was held in Beijing, our country opened college of coal, college of social work, logistics academy, textile college, institute of mechanical industry, automobile institute, institute of casting, institute of information security, institute of circular economy, college of software, over 10 industry colleges was established officially. Researches and practices on industry colleges have gradually carried out in universities, they trained lots of high-skilled talents, also showed its advantages and characteristics.

\section{First exploration on industry college was carried out in Shandong Yingcai University}

Though many local colleges and universities have gotten certain achievements on university-enterprise cooperation, but for major setup, they also have the problem of "not professional", which is hard to meet the special requirements of industry on talent training; the incorporation degree of university and enterprise is low, enterprises' management on employees' study is loose, the training quality cannot be guaranteed; part of universities' continuing education training costs is high, both enterprises and employees face large economic burden, which also influenced the training scale.

As the largest scale non-state-run school in Shandong Province, Shandong Yingcai University continues to explore talent training mode and education system, it constructed a enterprisecommerce cooperative platform through various channels. From the aspect of college orientation and transformation development, it held several times of discussion and seminar within the university and made a series of incentive measures. On December 23, 2014, our university signed with Shandong Fuda Decoration Group and established the first industry college "Fuda Decoration College" in Shandong to realize profound cooperation between university and enterprise. In order to establish industry college, our university did various investigation and negotiation, first chose the biggest decoration group in Shandong as our cooperative enterprise, meanwhile also selected the environmental design major which is with huge enrollment scale and market demand as our pilot.

\section{Organizational Structure}

After establishing Fuda Decoration College, dean is the deputy chief, board member of the enterprise, the headmaster personally issued the appointment letter for him, teaching dean is the experienced teaching administration staff assigned by the university. The university and the enterprise organize the "special direction committee" together, which consists of 5 deputy chief persons respectively from the university and the enterprise. The office of Fuda College is set in the university, the university is in charge of daily teaching management. The enterprise also sets office for teachers, they have special person contact with the university and supervise the teaching arrangement together. 


\section{Responsibility}

Both the university and enterprise undertake the teaching, daily management, semester assessment and students' graduation allocation of Fuda Decoration College, discuss to set out the talent training plan. Every year, the university will select 3-5 core teachers to practice in the enterprise, the enterprise organize a high-skilled mentor group, the university issue appointment letter for them, and invite them make academic guidance for students. Students' practical training, internship, practical projects are mainly guided by enterprise mentors. Dean of Fuda College will regularly take part in the important teaching activities of the university, teachers in the university will also regularly practice in the enterprise. Students' selection and evaluation is completed by both the university and the enterprise.

\section{Work}

The university-enterprise cooperative research is mainly carried out from 7 aspects, the relationship between the university and the enterprise is gradually straightened out, which has a positive function on major construction.

Discuss to make the talent training program

Establish a major construction committee, make the regulation and procedures of the talent training program into a written form, both sides should strictly enforce. Set environmental design major as an example, through many times discussion, survey, argument, maximum know the social and industrial demand, fully combine theory and practice, through cooperatively making talent training program by the university and enterprise to construct the resource and information sharing platform, specially set up Fuda class, set 5 courses that enterprise need most, strengthen education on enterprise culture, language communication and work ethic, train high quality talents of environmental design for local industries.

\section{Discuss to reform teaching mode}

Carry out teaching mode reform comprehensively, make the " $4+2+1+1$ ” talent training that integrates "technique, art and practice"three-dimensional through the teaching mode of "work-integrated learning, recycled type". The university and the enterprise analyze their own advantages and disadvantages, realize complementary through discussion. Enterprise leaders and the university management layer solve a series of problems in the teaching reform through regular teaching meeting, and put forward relevant solutions. For example, teaching place is not just limited in the classroom, but combine the classroom, construction site and enterprise factory, design department according to the learning of 8 semesters.

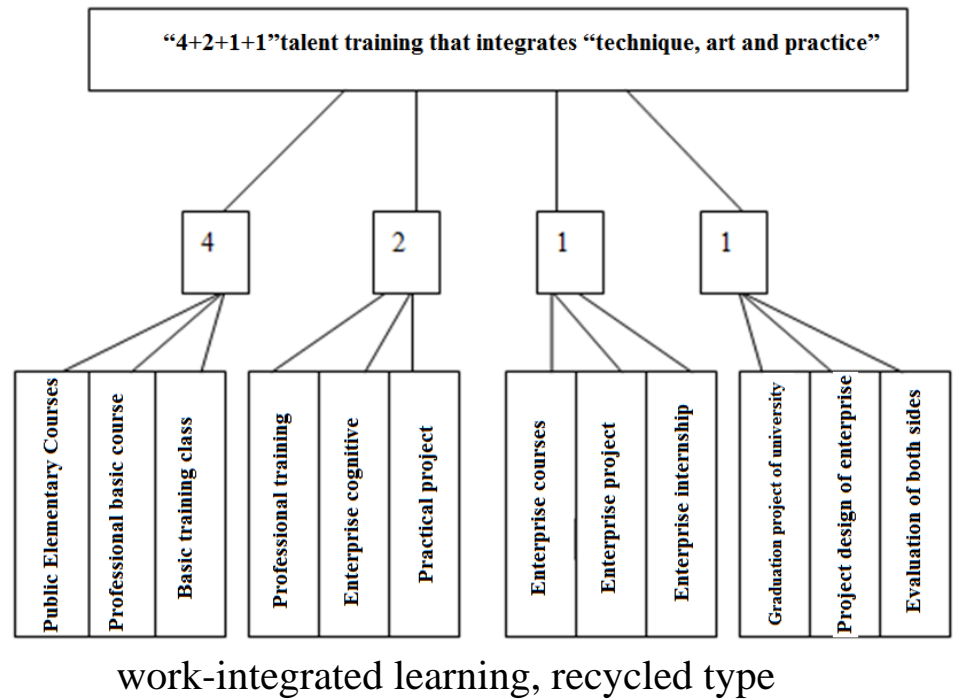

Jointly develop the curriculum system

Reconstruct the curriculum system of the environmental design major, set up modular-base curriculum system. The curriculum has been three-dimensionally set through analysis on vocational 
ability, employment position and sustainable development. Reintegrate the curriculum system through "base module", "professional promotion module", "practical training module", "comprehensive ability module" and "ascending module”, reset matrix, make efforts to cultivate the environmental design application talents who combine the technology of "professional, practical, cooperative, innovative" and art. Through many times of researches, we have made bold reform and innovation on the curriculums of project construction, material management, project approximate budget, glass curtain wall design and so on, try the curriculum content and method through integrating and following practical cases, the backbone teachers both from the university and the enterprise have taken part in the whole process, gradually developed 5 curriculum of project engineering management.

Jointly build the teaching team

The environmental design major requires teachers with high theoretical level, and some practical operating abilities. The industry college uses the interactive communication mechanism of the teaching building, the experienced enterprise teachers and teachers in the university carry out teaching together, through the close cooperation between the university and the enterprise to form teaching team and cultivate talents together. The university assigns teachers to practice in the enterprise to complete part of the actual mission. Teachers are employees, employees are also teachers, teacher exchange solved the insufficient of teaching faculty, meanwhile, also bring teachers' research result into the enterprise.

Jointly construct the training base

The students of the environmental design major need a large number of practical training, therefore, the matching training base is necessary. In the industry college, through the complementary and cooperation between university and enterprise to construct an open, cooperative training base integrating teaching, production, training and social service, the enterprise construct decorative materials laboratory and showroom, the construction site and glass curtain wall factory are good platform for students' internship.

Jointly responsible for students' employment

The employment problem is a social issue, is also one of the most important standard to measure the efficiency in university management, for students in the environmental design major of the industry college, the employment situation is also very serious. The talents training mode that serve enterprise, draws into excellent enterprise culture, adopts the training mode of university-enterprise cooperative education, lays a firm foundation for students' employment. Most of the students can be left to work in the enterprise, or be recommended to other strong decoration enterprise. Students' employment is the task of the university, also the task of the enterprise, through concerted efforts, the employment numbers and quality can be guaranteed.

Joint supervision on the quality monitoring system

Teaching quality is the most essential and core problem in profession talents training, in order to adapt to the education reform requirements of the industry college, the university and enterprise jointly apply the new teaching quality monitoring mode to realize jointly supervise on teaching quality. Regular to hold a summary conference on the teaching jobs, ask students representative and teacher representative to make a speech, make a detailed check-up system, evaluation system for the enterprise learning to evaluate the mentor in the industry college. Students' entrance education, semester assessment, graduation design and graduation thesis defenses are all arranged unified by the industry college.

\section{Achievements}

The college has got obvious achievements on the aspects of innovative university-enterprise education system, constructing university-enterprise cooperation unity and constructing university-enterprise cooperation information management platform; the personnel training orientation will greatly improve the training quality of environment design talents, further to strengthen students' application ability; the teaching mode and curriculum system are more conform 
to the actual needs of society, provides an effective learning platform of "research+ skill+ vocation"; teachers' practical teaching level has also been improved significantly, the ratio of teachers of specialized knowledge and technical ability has reached over $90 \%$; training base lays material basis for the win-win of the university and enterprise, students' employment rate has been improved significantly.

The industry college has been founded more 2 years, began to try out in students of 2013 grade. According to the teaching situation of 2015 and 2016, it has an obvious effect. At present, the environment design major has been evaluated by Shandong Province as the advanced and characteristic major in non-government institutions, the teaching team of decoration design has been evaluated as provincial teaching team, more than $90 \%$ of the teachers are senior engineer, senior interior designer, over $80 \%$ take part in the practical projects, at present, students of the industry college begin to undertake the design project of college students' growth pavilion and the innovative business incubators. Students are motivated, teachers are easier and easier.

\section{Existing problems}

The industry college makes full use of the different resource and environment of the university and enterprise, choose the environmental design major that highly matched with the industry and with large demand of talents and strong influence as a breakthrough, positioning according to the objective of "depend on local place, industry, face to the society and serve for economic construction and social development", positively explore the innovative mode of the training mechanism of the environmental design major. The current result is good, but also has some problems.

1). Except for the cooperative Fuda Decoration Group, enterprises that have ability and energe to train talents with the university are few, at present, the cooperative enterprise is relatively single.

2). There are a large number of achievements in the teaching process, but the depth and strength of the education reform still needs to be strengthened. For example, the practical projects that students take part in are change with the progress of the enterprise, there are many uncertain factors, teaching arrangement needs more flexibility.

3). The time is not long, the accumulated experience is still not rich, it still needs continuous exploration.

\section{Acknowledgments}

This paper is the research project of undergraduate education reform of Shandong Province in 2015, project No.: 2015M175

\section{Conclusion}

Though the exploration of industry college is still not deep, but the deep development of university-enterprise cooperation has been carried out, Shandong Yingcai University first sets industry college in Shandong province, which opens the new mode of university-enterprise cooperation, is a bold attempt for training application talents. The environmental design major has its own advantages and features on major construction and talents training, which is more benefit for tail. With the increase of students, the accumulation of experience, the perfection of education system, the reform of teaching method, the advantages of industry college will be more and more obvious.

\section{References}

[1] Zhang Lian. The theoretical problems of teaching-research-production cooperative education and the practice in China. Vocational and technical education (The class version), 2002,(34):21. 